\title{
Lesson Learned in Understanding Nature's Laws in Water Induced Disaster Management: Some Examples
}

\author{
Keshar M. Sthapit ${ }^{1}$
}

\begin{abstract}
Every year, there is unfortunate news about the property damage and loss of lives by the water induced disaster. Water induced disasters are the complex natural phenomena as an outcome of the rain and landform guided by the nature's laws. This paper describes some of the nature's laws essential to respect to live in harmony with nature. This includes consideration of angle of repose while using land, natural drainage to be respected during construction, hazard risk zoning to live in flood and landslide affected areas, fault line zone to be avoided for habitation, and toe of a slope is not to be disturbed to reduce slope failure. Water induced disasters such as erosion and flood are the nature's adaptation strategies to the changes in hydrological, physiographical and management or conservation status of the land caused by nature or human activities. Therefore, it is important to understand that these laws need to be understood and respected to live in harmony with nature so that effects and impacts of water induced disaster will be reduced.

जल उत्पन्न प्रकोपवाट धन जनको क्षति भएका दुख:द समाचारहरु वर्षेनी, समाचार माध्यमहरुमा आउँछन्। जल उत्पन्न प्रकोपहरु जटिल प्राकृतिक प्रक्रियाजन्य घटनाहरु हुन, जो मूलतः वर्षातको पानी र भू-बनोटको परिणामस्वरुप घट्ने गर्दछन्। यस लेखमा प्रकृतिसंग तारतम्य मिलाई जीवन जीउनका लागि मानिसले अनिवार्य रुपमा पालना एवं सम्मान गनुपर्ने केही प्राकृतिक नियमहरु वारे चर्चा गरिएको छ। भिरालो जमिन प्रयोग गर्दा माटो, गेगरान, ढुड़ा आदी अड्न सक्ने कोण (angle of repose) लाई ध्यान दिनुपर्ने, भौतिक संरचनाहरु निर्माण गर्दा पानीको प्राकृतिक वहाव अर्थात निकासलाई अवरुद्ध गर्न नहुने, वाढी, पहिरो प्रभावित क्षेत्रमा प्रकोप मापन गरी सुरक्षित क्षेत्र पहिचान गरेर मात्र वसोवास गर्ने, भौगर्भिक स्थिरताको दृष्टिकोणले कमजोर जमिन भित्र चर्किएको क्षेत्रमा वस्ती नबसाउने र पहिरो जाने सम्भावना घटाउन भिरालो जमिनको पिंध कटान गर्न नहुने जस्ता कुराहरु मानिसले पालना गर्ने पर्ने प्राकृतिक नियमहरुभित्र पर्दछन्। भू-क्षय, वाढी जस्ता जल उत्पन्न प्रकोपहरु, प्राकृतिक प्रकृयाहरु र मानवीय क्रियाकलापहरुको परिणामस्वरुप हुने जलचक्रीय, भौगोलिक र व्यवस्थापन वा संरक्षण अवस्थामा हुने परिवर्तनलाई अनुकुलन गर्ने प्राकृतिक रणनीति हुन् । त्यसकारण जल उत्पन्न प्रकोपहरुको असर एवं प्रभाव न्यूनीकरणको लागि यि प्राकृतिक नियमहरु बुकेर पालना एवं सम्मान गर्नु अपरिहार्य छ।
\end{abstract}

\section{Background}

It is a nature's law that water run down hill. More rain and more intense rain mean more runoff. Runoff runs quickly as the slope increased and cause more erosion. Every year, there is unfortunate news about the property damage and loss of lives by the water induced disaster. Water induced disasters mainly landslides and floods are the complex natural phenomena as an outcome of the rain (including snow) and landform. Erosion and flood existed since the origin of the water and is responsible to shape the earth to a beautiful plain, valley and hills.

\footnotetext{
${ }^{1}$ ICIMOD, Kathmandu, Nepal, Email: ksthapit@icimod.org
} 
Living in harmony with nature to be less affected by this natural phenomena make sense for economic and sustainability reason. Therefore, understanding of the key nature's laws is essential to reduce the effects and impacts of water induced disaster.

\section{Nature's laws}

This paper aims to describe some of the nature's laws required to understand to live in harmony with nature.

\section{Angle of repose}

Each slope has angle of repose. ${ }^{1}$ If slope angle is greater than the angle of repose, slope fails due lateral soil pressure. Angle of repose depends on soil texture, moisture content and conservation measures applied in the slope. In nature, with weathering underlying soil material changes, rainfall changes soil moisture status and with different human intervention conservation status changes, therefore, stability of the slope is dynamic. The stable slope now may not be stable tomorrow as these parameters change.

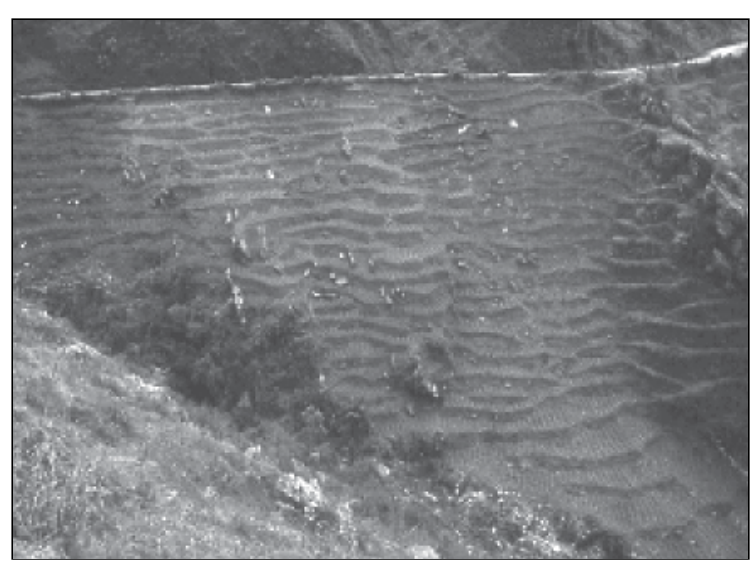

Figure 1: Steep land cultivation along Tribhuvan Highway (Dhading district)

Food requirement of ever increasing population is being fulfilled by cultivating steep slopes where one can hardly walk. If someone plows such steep slopes destroying all protective vegetation, do we not expect erosion or slope failure? If erosion or slope failure occurs, do we say it is water or human induced disaster? This is not the natural water induced disaster but human induced processes.

\section{Lesson learned}

Each slope needs to treat as per its suitability to live in harmony with nature's law for its stability.

\section{Natural drainage change}

Land surface (Geography) get stable at an angle of repose depending upon underlying materials, moisture condition, and conservation measures in place. So once the things change the slope has to change to come to stable position again. Developmental activities mainly road construction,

${ }^{1}$ The steepest and stable angle maintained by the granular soil material with the horizontal surface when heaped up on a surface. 


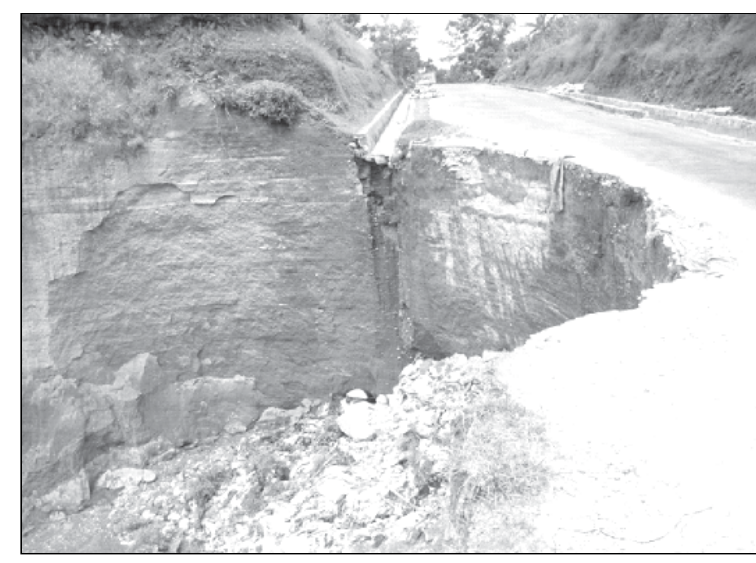

Figure 2: Concentrating drainage from larger distance causing erosion. Kathmandu- Pokhara Highway, Tanahu district

changes the micro hydrology of the natural drainage system disturbing stable slopes (Figure 2). Instability caused by changing micro hydrology of natural drainage system must not be considered as water induced disaster rather these are the results of misdeed to nature.

We observed that in the busy cities, if one road is blocked or disturbed other roads will be flooded with vehicles. Similarly, if any natural drainage system is disturbed other drainage will be flooded. Developments processes, mainly road construction block or change the drainage systems, which increase the flood in other channels. Have we ever guessed how much natural drainage has been narrowed, diverted or blocked while constructing infrastructures such as roads, building etc. that has increase flooding and slope failure?

\section{Lesson learned}

To minimize the water induced disasters such as landslides and floods, development works must not narrow, divert or block the natural drainage. Runoffmust be safely disposed without disturbing the natural drainage.

\section{Soil erosion processes}

Soil erosion is the process of detaching the soil particles by erosive agents such as water, wind and gravity from the land's surface of one place and it's transportation to another place for deposition. Therefore, it involves three distinct process namely detachment from the soil surface by eroding agent, transportation of detached materials to another place and deposition. Landslide in the Nuwakot district distinctly indicates these three different erosion stages (Figure 3).

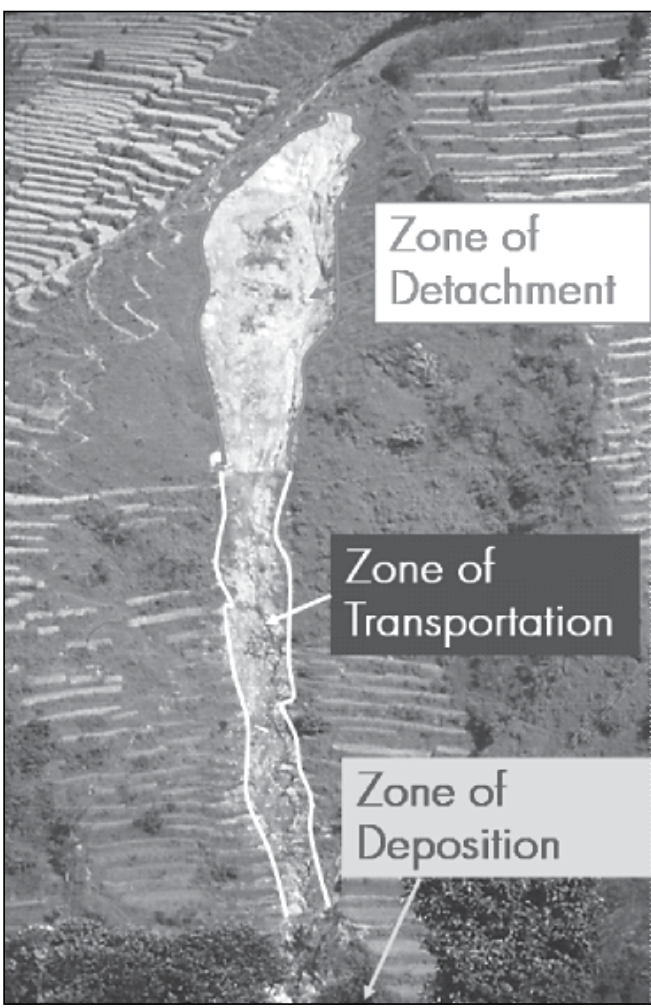

Figure 3: Landslide at Nuwakot with distinct erosion process 
Similarly, erosion process is distinctly observed in the watershed at large scale. In general, detachment process is dominant in the sloping area in the watershed (figure 4), transportation process is dominated in the sloping valleys (Figure 5) and deposition is dominated in the plain (Figure 6).

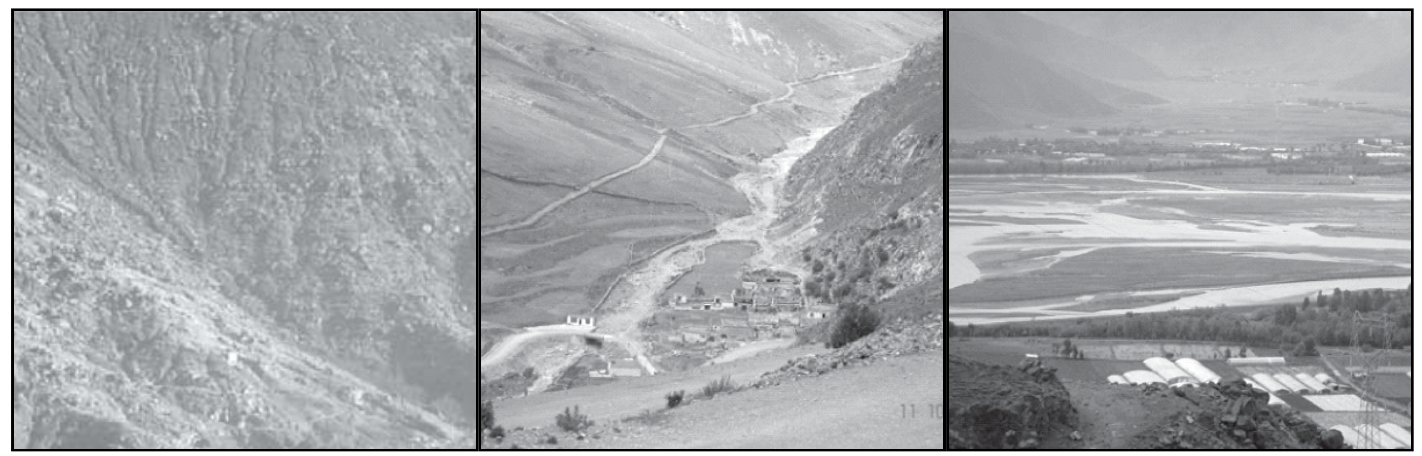

Figure 4: Sloping area in water- Figure 5: Sloping Valley area shed dominated by dominated by Zone of

Figure 6: Plain area dominated by Zone of Detachment Transportation the Zone of Deposition

\section{Lesson learned}

Different erosion processes are dominant in different zones of the watershed, so conservation measures required are different. Therefore, the focus has to be in proper land use practices in the upstream of watershed, stream bank erosion control in the transportation zones and river and sediment management in the plain.

\section{Flood}

Flood is a natural phenomenon to dispose the runoff quickly from the watershed and distribute the sediment in the flood plain. Overtopping of the natural or artificial banks of a river damaging property or human life is considered water induced flood disaster. Heavy rain and or intense rain results more surface runoff. Watershed depending upon its condition stores some rain water in watershed and rest will flow as runoff. If rain continues after complete saturation of the watershed, all rain will flow as runoff or rainfall more intensively than watershed can absorbs, excess rainfall flow as runoff. When $535 \mathrm{~mm}$ of rain at the intensity of $70 \mathrm{~mm} /$ hour intensity rainfalls in Kulekhani

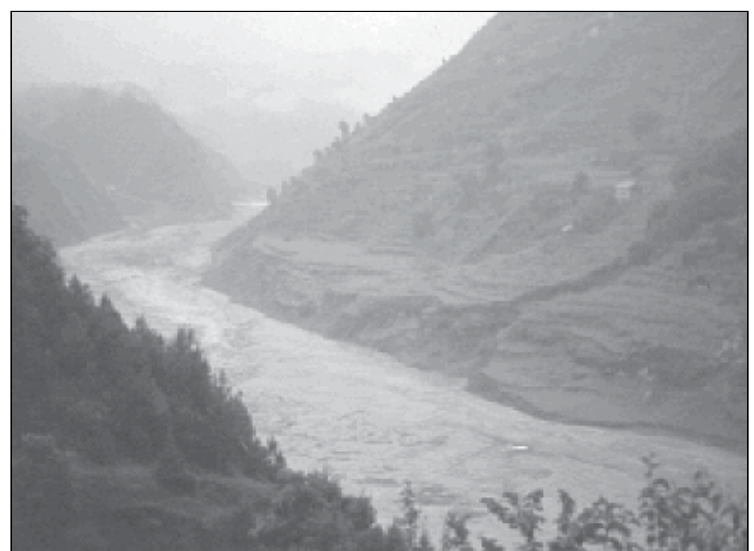

Figure 7: Flood in Kulekhani river, Makwanpur district in 20 July 2009 
watershed in a day (20 July 1993), there is no reason why the flood does not occurred killing dozens of peoples and damaging a lot of land and property (Figure 7).

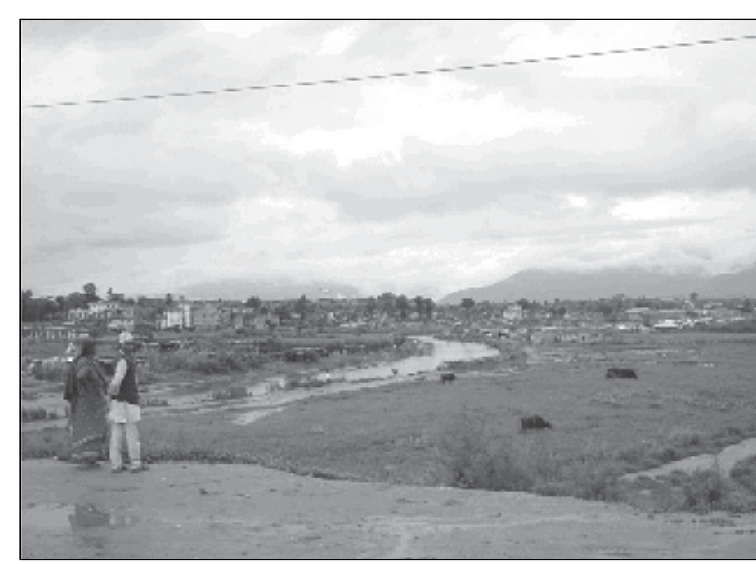

Figure 8: Habitation in Flood Plain along the side of Manohara river (Boundary between Kathmandu and Bhaktapur districts)
If somebody by force comes to live in one's house, definitely the person will kick the encroacher out of their house. We never consider this as inappropriate action. If people come to live in the waterways, there is nothing wrong if the flood wash away the people or damage infrastructures, which came to be in the waterways. Waterway in a river system is passage for the river to dispose the runoff of different frequency. If somebody is affected by flood just because they happened to be in the waterways, we should not considered it as water induced disaster but result of the misdeed of the human activities (Figure 8).

\section{Lesson learned}

Waterway is the river's right of way to drain the water, stay out of the waterways. Flood plain must be used as per the flood risk zoning.

\section{River training in the transportation zone}

Transportation zone is basically the passage for the sediment coming from the detachment zone whereas plain is meant for the management and distribution of sediment. Engineering river training measures, basically protection of property and habitation in the zone of transportation is recommended and make sense(Figure 9), whereas river training in the plain required more complex strategy rather than river training measures alone. Mitigation measures against disaster prevention from river in the plain includes strategies learning to live with river make more sense and appropriate than engineering

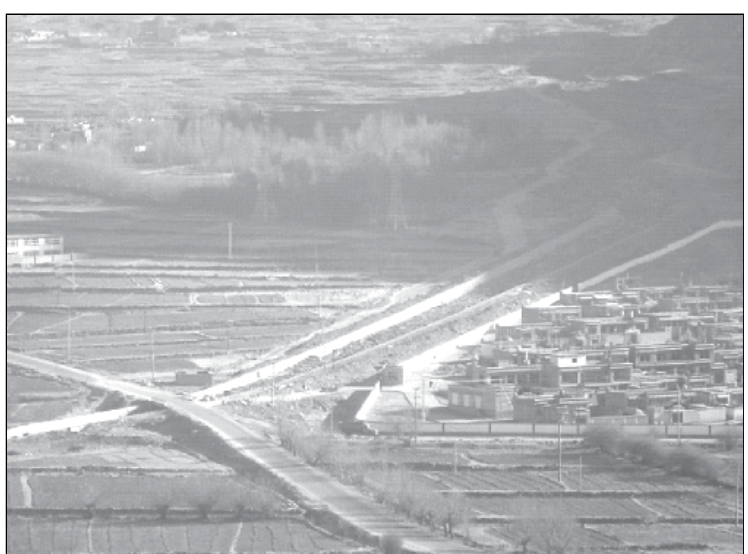

Figure 9: River training structure in Duodigou watershed, Tibet.

river training measures. Learn to live withriver following flood plain zoning, agriculture restructuring, and necessary flood disaster prevention mitigation measures. 


\section{Lesson learned}

River flows at different stages of waterway to dispose the runoff, depending upon the rainfall. Waterways are not for habitation. Engineering river training measures are appropriate in transportation zone whereas in the plain strategy along with river training measures, learning to live with flood need to be adopted.

\section{Flood control structures}

Embankment is the most commonly used structure to control flood in plain. Embankment confines the area for the river to distribute the sediment coming from the watershed. Sediment coming down will continue till the watershed degradation continues. As a result, river bed in plain will rise making the embankment lower. So to avoid the flood disaster, embankment height needs to be added. Time will come when the river bed is higher than the adjoining ground. Rise of river results water logging condition in the adjoining land. If such embankment breached, the damage will be enormous. In eastern Nepal, Koshi river breaching and damage caused in 2008 is the burning example of river bed rise. Moreover, nothing can be grown in water logged land than in flood affected land.

\section{Lesson learned}

River system is natural features for draining the runoff and sediment from the watershed. It has to remain lower than the adjoining land otherwise river has to shift. Watershed management to reduce sediment, sediment management within the watershed and plain including its distribution and control and living with flood as per flood risk zoning and cropping remodelling, will be the more appropriate strategy in the flood plain as mitigation measures in long term.

\section{Tectonic movement makes fault line subject to mass movement}

In the seismic zone, because of tectonic movement along the fault zones lands became very fragile. No matter what conservation measures are implemented, these zones became very disaster prone (Figure 10). Therefore, recognizing these zones habitation must be avoided.

\section{Lesson learned}

Fault zone is not for habitation.

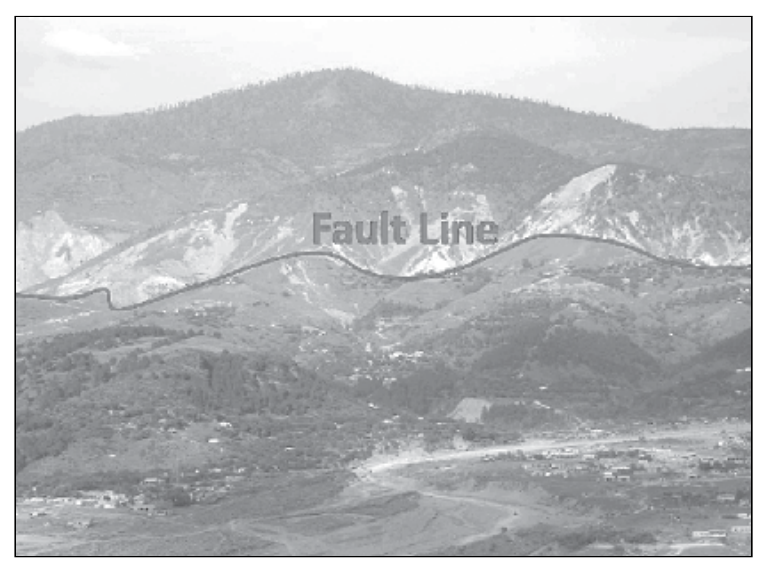

Figure 10: Fault line at Gulmera, Gadhi Habibulah, NWFP, Pakistan 


\section{Landslide rehabilitation}

Heavy rainfall (300mm/day starting $22^{\text {nd }}$ July 2002 Monday to $23^{\text {rd }}$ July 2002 Tuesday), triggered several landslides around the Matatirtha VDC in Kathmandu valley causing damages to the lives and property. One of the landslides

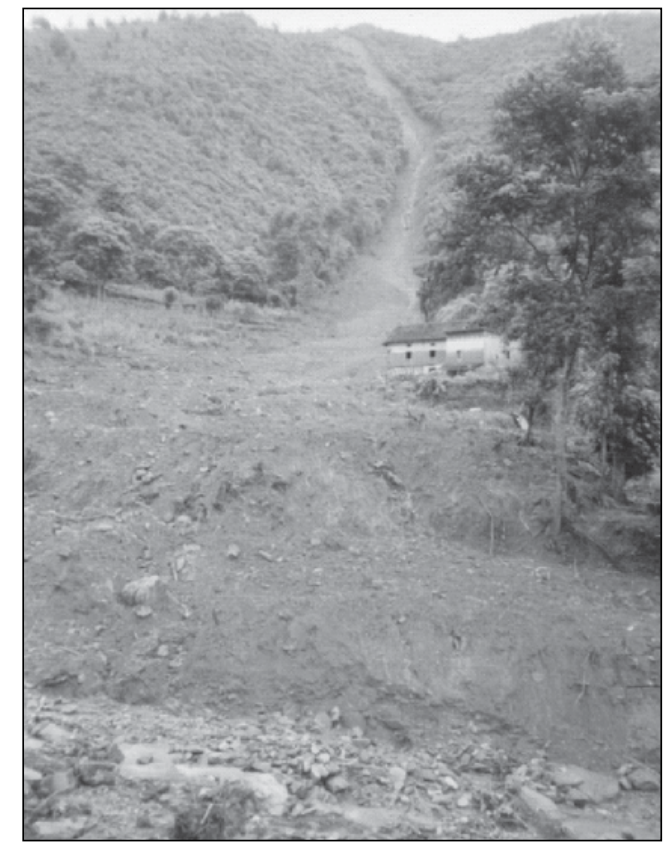

Figure 11: Matatirtha landslide, Kathmandu valley, July 2002 killed 16 people and completely destroyed 7 houses, a temple, a culvert, and destroyed partially 2 houses, the local road, primary school and corn-field (Figure 11). There was a big public pressure on the government to take necessary measures. As a result, Government took a several measures to rehabilitate the landslide and affected areas in one of the sites where 16 people were killed. This includes construction of check dams, retaining walls, and planting of grass and trees.

After about few years the site is recovered (Figure 12). Amazingly, in one of the landslides South West side of the Matatirtha spring occurred in the same event recovered with the natural vegetation (Figure 13) without any conservation measures similar to the area where government carried out rehabilitation measures spending million of rupees. Geology, slope and climate remaining same, it indicates that nature has tremendous capability rehabilitate the degraded area remaining no biotic interference (Figure 14). Because of the people killed, government is forced to implement rehabilitation measures in one site, whereas in another site fortunately no one is killed and public did not generate pressure for rehabilitation measures.

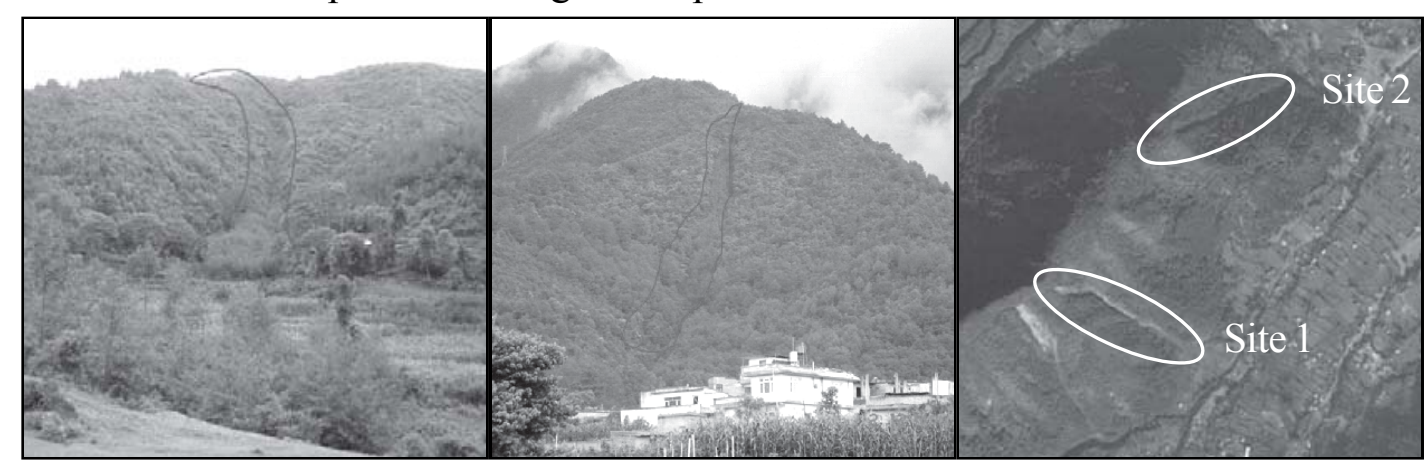

Figure 12: Matatirtha landslide, Site 1, where rehabilitation measures were carried out, July 2007
Figure 13: Matatirtha landslide, Site 2, West side of spring, naturally recovered, July 2007
Figure 14: Google Earth image showing landslide of two sites 
Closely observing the landslides, it clearly indicates that depending upon the geomorphology of the site, the area affected can be predicted through modeling. Based on geomorphology if hazard risk zoning of such area could be carried out and bring to the notice of the public as well as planners. This will be the basis for the government for planning housing and for public to choose where the house should be built. If this system was there, neither will the people be killed by such event nor will there be any pressure to the government to carry out rehabilitation measures, since such sites will be recovered by the nature without any cost.

\section{Lesson learned}

Landslide hazard risk mapping will play an important role and must be emphasized to reduce loss of human lives and damage to property.

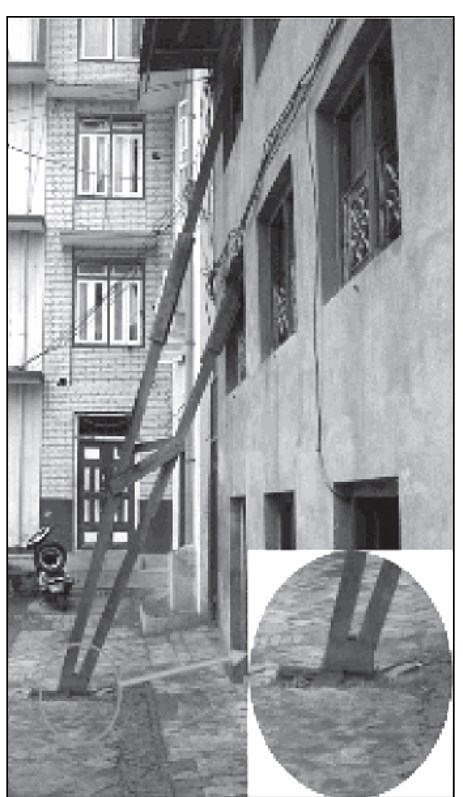

Figure 15: Protecting building with small wooden support

\section{Toe protection}

A small wooden peg supports a big building from falling (Figure 15). Similarly, all hill slopes have their own toe to support. However, in the name of development we happened to cut the toe or make the toe cutting and create unstable slope resulting failures. Recognizing these toes of the slope and protection of these toes of the hill slopes is essential if slope failures occurrence is to be reduced and protect human lives and properties.

\section{Lesson learned}

Development activities must not weaken the toe of any slope. If toe slope is affected necessary measures to strengthen the toe must be an integral part of the development.

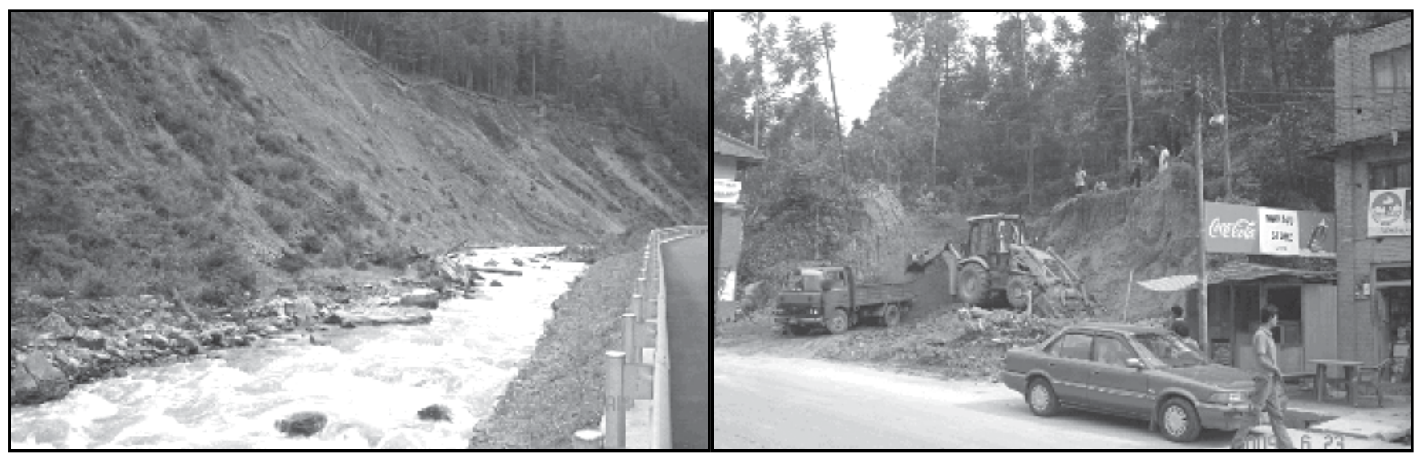

Figure 16: Road construction push the river other side erode the toe of the slope

Figure 17: The toe cutting of the slope for increasing slope failure construction 


\section{Erosion}

In the steep slopes, vegetation does not grow in the lack of moisture and base for the plant to grow (Figure 18). Slope correction with erosion build the slope better for the growth of the vegetation. Most of the terrace slopes with erosion modify the slope so that plant can grow (Figure 19). Some of the most fertile agriculture land happened to be the foot slope, plain or fans (Figure 20) built from the debris of landslide, fluvial or colluvial processes. Erosion has carved all interesting features in the earth for human being to live.

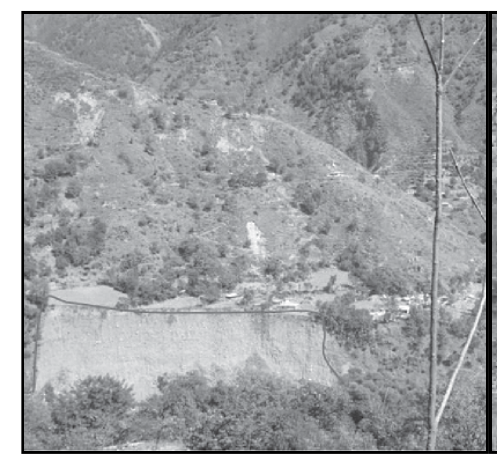

Figure 18: Steep terrace slope unfit for any vegetation-Lamnia Watershed, AJK, Pakistan

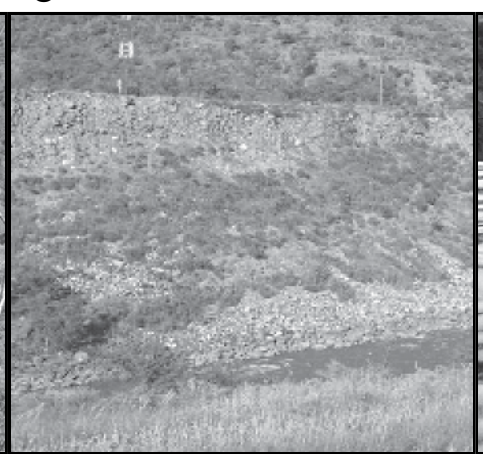

Figure 19: Erosion of steep terrace build modified slope for vegetation growth, bank of Jhelum river, Pakistan

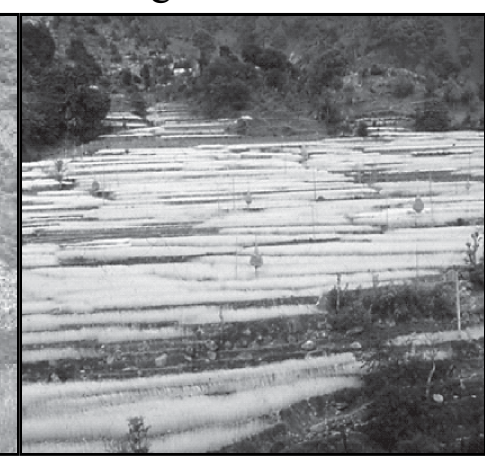

Figure 20: Productive agriculture land is the fan developed from fluvial deposition, Tibet

\section{Lesson learned}

Erosion is an essential phenomenon in the nature's scheme. It is better to understand the natural processes and live in harmony with nature.

\section{Conclusion}

Knowingly and unknowingly, different activities are carried out without or with less respecting the nature's laws affecting the stability of the slope thus resulting water induced disaster causing loss of human lives and property. Here we have to question ourselves that are we

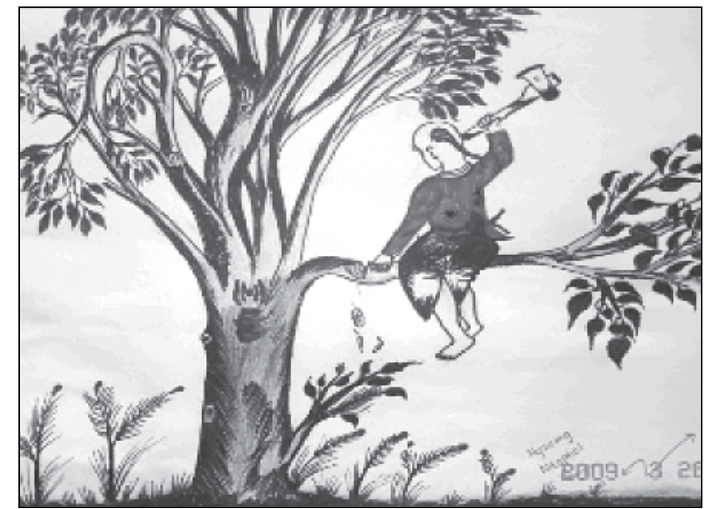

Figure 21: Kali Das cutting branch sitting on the wrong side of the branch. better than Kali Das, who is cutting tree branch sitting on the wrong side (Figure 21) in managing natural resources mainly land and water. Is not the increased water induced disasters are the result of man's misdeed to nature without understanding nature's laws? Therefore, it is very important to understand the nature's law and adopt strategy accordingly to live in harmony with nature otherwise because of misdeed of the human water induced disaster will be more and cause damage to human lives and properties in future. 